Towards a Philosophy of Equity in Educational Effectiveness Research: moving from utilitarianism to a Rawlsian paradigm

\title{
Anthony Kelly
}

Colum Elliott-Kelly

School of Education,

University of Southampton,

Highfield

Southampton S017 1BJ

Email: a.kelly@soton.ac.uk 


\title{
Towards a Philosophy of Equity in Educational Effectiveness Research: moving from utilitarianism to a Rawlsian paradigm
}

\begin{abstract}
The uses to which educational effectiveness research (EER) are put by policymakers cannot be blamed on the field, but it is apparent that it has become aligned with the utilitarianism of western government policy and transnational bodies like OECD. This alignment was not consciously adopted - it is more the case that in the absence of its own asserted philosophy, EER simply defaulted to that world-view - but as the field shifts to a 'dynamic' model and meta-syntheses, the need to reconsider the current paradigm becomes urgent. This paper attempts to reclaim the field philosophically for the academics who work in it and for the policy-makers who rely on its science. It is beyond the scope of the paper to present a full comprehensive philosophy, but describes, as a first step towards one, a new manifesto based on John Rawls's work on justice as fairness.
\end{abstract}

KEYWORDS: Philosophy, Equity, Educational Effectiveness, utilitarianism, Rawls

Acknowledgement: The author would like to thank Prof. Leonidas Kyriakides for his helpful comments on an earlier draft of this paper. 


\section{Introduction}

Educational effectiveness research (EER) investigates the extent to which schools achieve their aims effectively and efficiently. It accepts that differences in pupil attainment are largely determined by intelligence (or 'reasoning ability') and socio-economic factors, but that schools can, and do, make a significant difference. It attempts to explain to what extent, and why, those differences vary from school to school and between societies and communities. ${ }^{1}$

EER is a quantitative, institutional-focused approach that began in earnest in 1979 (Edmonds, 1979; Brookover, Beady, Flood \& Schweitzer, 1979; Rutter, Maughan, Mortimore, \& Ouston, 1979). As time passed and with the advent of more sophisticated approaches to data modelling, EER secured its place at the cutting edge of educational research, 'doing the science' upon which so many national policies and international comparisons depend (Dobert \& Sroka, 2004). It involves measuring a school's output in terms of pupil attainment, correcting for input, circumstance and context, and assigning a scalar to what the school adds in value. However, two serious problems remain unarticulated. Firstly, there is a set of 'approach' issues: the fact that the act of measurement itself affects what is being measured because schools learn to optimise the metrics; the lack of engagement with technology and its impact on attainment; the difficulty of incorporating non-cognitive and meta-cognitive outcomes into the measurement; and the need to research the relationship between cognitive

\footnotetext{
${ }^{1}$ There is a distinction to be made between 'society' and 'community'. Neither utilitarianism nor Rawls (1971) have much to say on the subject, but the noted Scottish philosopher John Macmurray (1957) regarded society as a construct for organisations to achieve particular purposes, while community was an end in itself (McIntosh, 2004).
} 
functions and psychomotor learning. Secondly, there is the overarching issue that EER has not developed any coherent philosophical underpinning. The two problems are linked because a philosophy drives what is being measured, the use to which the measurements can legitimately be put, and the critiques that can be made of any comparisons. The absence of an articulated philosophy for EER and the fact that it has too often been atheoretical (Creemers, 2002; Scheerens, 2014) - may be the result of paying so much attention to methodology and to the rich datasets available to which that methodology could be applied, but methodology alone does not create a discipline and the philosophical shortcoming is starting to affect EER adversely in a number of ways:

- Many researchers in the field are moving to discuss 'equity' without defining what it means in terms of justice or fairness. Equity in EER has generally been regarded as synonymous with contextualised sameness, although a recent paper by Charalambous, Kyriakides and Creemers (2016) that discusses some philosophical implications may start a trend in the field.

- Transnational bodies like the Organization for Economic Co-operation and Development (OECD) continue to play down the importance of context when making international comparisons. Having an appropriate philosophy would better enable EER to make constructive critiques of these comparisons.

- There is general agreement that communities need effective schools, but there is no acknowledgement that this can exacerbate differentials in achievement; schools can improve in aggregate, but adversely affect 
disadvantaged pupils. Having a philosophy would enable EER to

reexamine fundamentally the consequences of aggregation.

EER looks at variations in practice between schools and between classrooms with a view to understanding why and how some schools, but not others, make educational outcomes for disadvantaged pupils more equitable and fairer. The challenge for the field is to debate and define what is meant by terms like 'fairness' and 'equity', and to be self-conscious about the philosophical implications of those definitions. EER has focused on issues of quality rather than equity (Creemers \& Kyriakides, 2015), but has a long tradition of addressing the attainment gap between the 'haves' and the 'have-nots' (Sammons, 2007). However, by default it has succumbed to a transnational utilitarianism where equity is regarded merely as the maximisation of aggregated utility² (Mas-Colell, Whinston \& Green, 1995). This paper suggests that such utilitarianism is restricting and inappropriate for the moral imperatives at the heart of EER, and that an alternative philosophy based on Rawls's theory (1971) of 'justice as fairness' is one way forward for the field. ${ }^{3}$ This is particularly important as EER adopts a more theoretical 'dynamic' model (Creemers \& Kyriakides, 2006 \& 2008) that treats equity, measured crudely by the size of the attainment gap between disadvantaged and non-disadvantaged pupils, as a critical internal component.

\footnotetext{
${ }^{2}$ Utility is a measure of the preference that a consumer has for a particular set of goods or services and represents the satisfaction experienced by the consumer from the good. The concept is important in rational choice theory because one cannot measure benefit directly. In its simplest form, economists consider utility to be revealed in people's willingness to pay different amounts for different goods.

${ }^{3}$ It is beyond the scope of this paper to present an 'archeology' of EER or to explore all possible applications of Rawls's (1971) work to the field. The purpose is to identify the shortcomings of utilitarianism and to introduce Rawlsian theory as an alternative philosophy.
} 


\section{Part 1}

\section{Utilitarianism and its relationship to EER}

Utilitarianism is a group of philosophies that developed over the course of more than a century. In its original form, as developed by Jeremy Bentham (1780), ${ }^{4}$ it holds that the best action is the one that maximises 'utility' for the greatest number of people. 'Utility' is the sum of all the benefit, minus the detriment, that results from an action. In an educational setting, we can equate it with attainment and achievement; what could be termed 'educative benefit'.

The two defining characteristics of utilitarianism are the aggregation (or averaging) of benefit, and a reliance on the measurement of proxy outcomes. ${ }^{5}$ In utilitarianism, as with EER and school improvement research (SIR), actions are judged by their tendency and expediency. The outcome of any action is the sole measure of whether it is right or wrong. Just as SIR differs from EER on the basis of methodology, so utilitarianism comes in several forms determined by their preferred methods for measuring utility. 'Total' utilitarianism, for example, holds that utility should be calculated as an aggregate, whereas 'average' utilitarianism holds that it should be calculated as an average. Henry Sidgwick, in his 1874

\footnotetext{
${ }^{4}$ Actually the underpinning idea predates Bentham by more than sixty years. Francis Hutcheson (1726) first introduced the idea that virtue is in proportion to the number of people deriving benefit from it, and that the best action is therefore the one that procures the greatest happiness for the greatest number.

${ }^{5}$ Bentham (1780) and Hutcheson before him (1726) even developed a 'hedonic calculus' for measuring the happiness generated by an action.
} 
book The Methods of Ethics, ${ }^{6}$ discussed the question of aggregate versus average utility, concluding that what should be maximised is the average utility multiplied by the number of people in the population. The consequence of this is that if average utility stays the same, utilitarianism commands us to make the number of people benefitting as great as possible. This might seem sensible, but problems of moral alignment emerge in an education setting. Maximising aggregated utility can lead to the situation where large numbers of pupils with very small educative benefit is regarded as a better outcome than a smaller number of pupils with larger benefit, but this might not be what a society needs at any given time. And maximising average utility can mean ignoring all pupils whose educative benefit is below average, which might not be what a community wants at a given time.

Bentham's book An Introduction to the Principles of Morals and Legislation was published in 1780. It states the principle of utility as:

... the principle which approves or disapproves of every action whatsoever according to the tendency it appears to have to augment or diminish ... happiness (Chapter 1; Section II).

In Chapter 4, Bentham introduces his 'hedonic calculus'7 in which he claims that the value of a pleasure can be measured by, among other things, the number of people affected. Hutcheson (1726) eventually rejected this algorithm as 'useless

\footnotetext{
${ }^{6}$ Interestingly, the seventh edition, Sidgwick, H. (1981) Methods of Ethics (New York: Hackett Publishing), has a preface written by John Rawls.

${ }^{7}$ So called because utilitarianism can be traced to ancient Greece and Epicurean hedonism.
} 
and disagreeable', but Bentham could see 'nothing unwarranted' in it. In a way, this is a philosophical echo of today's fixation in education with measuring the achievement of intangibles, or failing that, concentrating on what is measurable and ignoring important factors that are difficult to gauge. Despite the advocacy of Creemers and Kyriakides (2008) whose dynamic model proposes including nontraditional metrics like well-being (see also Opdenakker \& Van Damme, 2000), EER has sometimes been driven unwittingly into a spurious calculus by policymakers who see the convenience of a utilitarian view of schooling. This 'official' outlook has been secured through targeted funding from government and quasigovernment sources like research councils, and the privileging of certain lines of academic inquiry and econometric methods at the expense of other approaches.

In Chapter 7 of his magnum opus, Bentham (1780) notes that in trying to promote greater utility in society, 'governments should punish' in proportion to the extent to which certain actions are 'pernicious', ${ }^{8}$ which reflects the recent views of education policy-makers about accountability and 'naming-andshaming'. This is not to blame EER for the uses to which it is put, but rather to show how well-aligned it has become with the utilitarianism of western government policy and that of transnational bodies like the OECD. In the absence of any asserted philosophy to the contrary, policy-makers have steered EER towards this world-view and their utilitarianism has become the default paradigm of EER.

\footnotetext{
8 In his book Theory of Legislation, Bentham (1780) distinguishes between 'evils of the first and second orders' First-order evils have immediate consequences; second-order evils occur when consequences spread through society causing disruption, and it is the latter that 'makes punishment necessary'.
} 


\section{The contribution of Mill and modern utilitarianism}

John Stuart Mill was a follower and promoter of Bentham's utilitarianism, but his book Utilitarianism, published in 1863, rejected as absurd the purely quantitative measurement of utility. Mill was anti-hedonistic, asserting instead the 'pleasures of the intellect', but agreed with Bentham that the welfare of the majority should be paramount. In Chapter 4 of Utilitarianism, Mill offers his famous proof for the principle of utility: that greater utility is desirable and 'a good to the aggregate of all persons' because people make it so, in the same way that the proof that an object is visible is that people can see it. This 'notorious' (Alican, 1994) argument is fallacious on several counts. Firstly, Mill is inferring what people ought to do from what they actually do; a naturalistic fallacy. Secondly, he is inferring that something ought to be desired from the fact that something is capable of being desired; a fallacy of equivocation. And thirdly he is inferring that because people desire greater utility for themselves, that the aggregate of all persons will desire greater utility generally, and that it will be the only thing they desire.

The Twentieth Century saw the development of 'act' and 'rule' utilitarianism, which emphasise the central role of regulation in helping people chose the course of action that maximises utility. The difference between act and rule lies in how the action is judged to be the right one. Act utilitarianism holds that an action is right if that action maximises utility, whereas rule utilitarianism maintains that an action is right if it conforms to a rule that maximises utility. Richard Hare $(1973,1981)$ suggests that the difference between act and rule utilitarianism is really about the general versus the specific. He developed a 'two- 
level utilitarianism' bringing forth a distinction between 'specific-rule' utilitarianism, which collapses into act utilitarianism, and 'general-rule utilitarianism', which does not. Hare (1973) suggests that we use specific-rule utilitarianism when we are deciding principles to follow, but we use general-rule utilitarianism when we are in situations where our natural bias is likely to prevent us from calculating properly the best course of action. Hare (1981) illustrates his two-level utilitarianism in a type of thought experiment not dissimilar to that of John Rawls (1971) a decade earlier. He conjures up two archetypes to represent the two extremes of general and specific. The 'Archangel' is a hypothetical person who has perfect knowledge of every situation and no personal bias, and always uses critical thinking to do the right thing. The 'Prole', on the other hand, is completely incapable of critical thinking and uses only intuition, and from necessity blindly follows general rules. ${ }^{9}$

Hare (1981) might have saved EER a lot of time and effort if he had specified when and under what conditions people act as Archangels and when they act as Proles, but he did not. What is important in Hare's dramatic device is the primacy of the formal critical thinking of the Archangel over the experiential intuition of the Prole. EER has come to treat the primacy of its own modeling versus the intuition of teachers in a similar way, a fact that is acknowledged implicitly in the dynamic model of Creemers and Kyriakides (2008). It is quite proper that autonomous practitioners should default to critical thinking when working in unusual situations, but in the context of professional practice, whether in schools

\footnotetext{
${ }^{9}$ Hare (1981) is not suggesting that people are innately either Archangels or Proles, but that everyone has the characteristics of both to varying degrees, and in different contexts and at different times.
} 
by teachers or in hospitals by doctors, it is a mistake to regard professional intuition as being devoid of criticality. The dichotomy between critical thinking and intuition is a false one. It privileges thought over action in all situations and has been robustly critiqued by 'personalist' educational philosophers like John Macmurray (1957). The Prole cannot be both robot and trained professional, whether the context is medical triage or classroom practice, and conversely the Archangel cannot be devoid of bias and uncertainty. That much is obvious from the decades of claim and counter-claim in EER (Gorard, 2014a \& 2014b).

Utilitarianism also ignores emotion as a motivating action and excludes preferences like jealousy and generosity (Harsanyi, 1975, 1977). Utilitarianism demands only that aggregate educative benefit be maximised, so anything that does not facilitate that is disregarded.

A sacrifice which does not increase ... the sum total of happiness is ... wasted. (Mill, 1863, Ch.2)

This is reflected in the current paradigm of EER in that peer effects like bullying, friendship and an altruistic willingness to help others are, with some exceptions (e.g. Kyriakides, Creemers, Papastylianou \& Papadatou-Pastou, 2014), largely ignored. There is no recognition given to the impact of these factors on outcomes or to the impact of measurement on these factors. It seems that the veins of utilitarianism run through the body of EER both in terms of how data is selected, collected and treated, and in what is ignored. 


\section{The wild, the innocent and the greater good}

Utilitarianism implies a willingness to disadvantage some for the greater good. It might seem that this is a shortcoming specifically of act utilitarianism because rule utilitarianism could prevent it with rubrics of one sort or another, but it is equally plausible that the right rubric might not address the right issue at the right time, and rectifying the matter post facto is no consolation for those who have been wronged, even if someone else at some stage in the future is thereby saved from a similar fate. Equity and fairness cannot be transferred in a zerosum manner and the question for EER is whether it can accept such an approach to schooling; namely, that some pupils are treated unfairly because the greater good is served by ignoring their plight. The fundamental problem is that educative benefit is aggregated in utilitarianism, although few educationalists would accept that one pupil's deprivation can be outweighed by another pupil's achievement. ${ }^{10}$ EER has a proud history of carrying out robust empirical research so that educationalists can chose the most effective course of action towards an end determined by policy-makers, but it needs to identify and articulate the moral impulse behind those policies and decisions. After all, education is a moral, not an economic, endeavor and EER should articulate some immutable ethic beyond the vague notion of 'greater equity', which itself has not been defined beyond having a methodology for measuring the attainment gap between disadvantaged and advantaged pupil groups.

\footnotetext{
${ }^{10}$ Karl Popper (1945) suggested that instead of 'the greatest happiness for the greatest number', we should look instead at 'the least amount of suffering for the greatest number', but this still fails to address the problem of aggregation.
} 


\section{Part 2}

\section{Rawls's theory of justice and its relationship to EER}

John Rawls published $A$ Theory of Justice in 1971, in which he offered a convincing alternative to utilitarianism. ${ }^{11}$ His work is a practical attempt to address the tension between liberty and equality in a democratic society, and in that sense it speaks to the underpinning objective of EER. In contrast to utilitarianism, which holds to the single universal moral principle of maximising utility, Rawls offers no equivalent universal principle because 'the correct principle for anything, depends on the nature of that thing', on the actors in question and on context (Rawls, 1971, p.29-30). Rawls also acknowledges that in a democratic society, people will have different opinions and priorities but there can be only one law, and this presents two difficulties. Firstly, there is the difficulty of having the state exercise coercive political power to force everyone to follow the same set of laws. This is the 'Principle of Legitimacy'. Secondly, there is the difficulty of having people willingly obey the law when the law is proposed and imposed by a ruling group whose members probably have different beliefs and values. This is the 'Principle of Stability'.

Rawls (1971) addresses these two challenges head-on. His test for 'legitimacy' is that the law is exercised in ways that all stakeholders can endorse and fulfills a

\footnotetext{
${ }^{11}$ He further developed his ideas in his lectures at Harvard. It is beyond the scope of this paper to explore fully Rawls's motivation in developing his theory of justice, but he had a record in the mid-1960s of opposing the exemptions offered to university students who wanted to avoid being drafted to fight in the Vietnam War. His view was that the children of better-off parents - and the vast majority of university students at that time fell into that category - had no right to preferential treatment of that sort; and that the waging of a war was only justified if the burden was evenly shared by all sections of society.
} 
criterion of reciprocity whereby everyone believes that everyone else will also accept enforcement. Admittedly everyone has their own 'comprehensive doctrine' - their own set of religious and political beliefs and values - but they are unwilling to impose those doctrines on others. Instead, they will seek out, and abide by, mutually agreeable rules as long as they are not based on the comprehensive doctrine of any one cohort. Rawls's test for 'stability' - where people are willing to obey laws that are 'imposed' by a ruling group whose members may have different beliefs - is based on his idea of an 'overlapping consensus'. In this concept everyone endorses the same core set of laws, but for different reasons. People support their own ideas of equity and justice consistent with their own comprehensive doctrines, but the core set of laws is common to each doctrine and is therefore supported by everyone. Rawls regards social stability based on an overlapping consensus as a better form of stability than one based on balance of power, but such stability is impossible to achieve when there is not sufficient overlap between different sections of society and when there is no convergence on liberal notions of equity. It is important that this political difficulty does not find its way into the formal structure of schooling by having the state support schools that promote illiberal ideologies, and it is important that EER is alert to these dangers and that the metrics that gauge effectiveness, such as using ethnicity to 'contextualise' value-added measures, do not offer perverse incentives towards divergence and intolerance.

All this is held together in Rawls's (1971) theory by a 'spirit of public reason': the belief that people will justify their political decisions to one another in a respectful manner and only by referencing publicly accepted (and not personal) 
values. Basic constitutional essentials act as overarching guidelines in respect of these publicly accepted values - the right to vote, the right to own property, and so forth - but Rawls does not hide from the tension created in public discourse between the aspiration to create a just society and the rights of the individual. This is also the case with public schooling. The right to maintain good schools for everyone, as part of what Rawls calls the 'basic structure', can be at loggerheads with the rights of individual parents to raise their children and to spend their money as they see fit, even if doing so benefits their children at the expense of the system by going to private schools. For this reason, Rawls sets about establishing some fundamental principles for the basic structure of social institutions like schools using a novel approach.

\section{The veil of ignorance and the original position}

The most distinctive part of Rawls's (1971) theory is the thought experiment in which the principles for the basic structure are chosen in a way that forces all individuals to choose only those rules that are fair and justifiable to everyone. Rawls proposes a 'veil of ignorance' behind which individuals (or their representatives) do not know anything about themselves or their society, so they do not know which choices will positively affect them. Behind the veil, nothing is known about ethnicity, social class, innate ability, intelligence, age, or the structure and current state of affairs of society. This baseline of ignorance is what Rawls calls 'the original position' (see Hinton, 2015) and he regards it as the best method for reaching a 'reflective equilibrium' (Mandle, 2009, p.17). 
Everyone in the original position is concerned that their own fundamental interests are at risk from the choices made, so everyone has the incentive to choose principles that protect everyone's fundamental interests. It is similar to the maximin strategy in game theory where a party chooses the action that produces the best of the worst possible outcomes. The veil of ignorance deprives people of all knowledge about themselves, but everyone is aware of the uncontroversial findings of science; for example, everyone in the original position choosing principles about education and schooling would be aware of the scientific findings of EER and the factors that impact on pupil attainment.

Since the actors do not know their own natural endowments or circumstances, they do not advocate for any one set of attributes over another. Such an approach could be useful in addressing some thorny issues in education. Without knowing their own children's intellectual abilities, would parents favour the expansion of academically selective schools? If parents were unaware of their own financial situation or social status, would they be in favour of private schools? With no knowledge of their children's natural abilities, would they favour or oppose more resources being spent on remedial education? What educational choices would parents in the original position make about ability streaming? Without knowing whether or not their own children would be affected, what would their preference be in areas like discipline and the provision of extra curricular activities? These are all questions that the utilitarianism of EER cannot address beyond requiring that the majority should benefit, but which a Rawlsian approach can address by using the veil of ignorance device. Admittedly they are political rather than research effectiveness 
questions, but they do inform the paradigm that drives research in the field and against which the impact of research is ultimately judged.

\section{Rawls's two Principles of Justice}

Under the conditions of the original position, Rawls (1971) suggests that the following two principles will emerge from behind the veil of ignorance:

(i) Everyone will agree to guarantee basic democratic liberties for all. According to Rawls, this principle will be actualised by the political institutions of society's basic structure and cannot be traded off against other social goods or against economic prosperity.

(ii) Everyone will agree that to allow any socio-economic inequality, it must satisfy two conditions:

(a) everyone is to have a fair chance of filling the desirable positions in society. Equally gifted people with the same willingness to use those abilities should have equality of opportunity regardless of social status.

(b) inequality is justified if and only if it works for the benefit of the most disadvantaged; in other words, for inequality to be accepted, everyone, especially the disadvantaged, must benefit, though perhaps not to the same extent. This is called the 'difference principle'. It is based on the premise that the distribution of natural assets and abilities is undeserved. A pupil 
does not deserve greater advantage simply because he or she was lucky enough to be born with certain abilities. This is not to say that everyone must get the same share of society's goods or nature's bounty, but it means that the distribution of natural ability should be treated as a common asset that benefits everyone. Those lucky few who are better endowed by nature can use their innate gifts to make themselves better off, as long as they make the disadvantaged better off as well.

According to Rawls (1971), both parts of the second principle will be actualised by the social and economic (rather than by the political) institutions of the basic structure, and this includes schools. Schools act to drive up social mobility and remediate on behalf of pupils from disadvantaged backgrounds, but the challenge for schools is more nuanced than this in a Rawlsian paradigm. Inequality is something that should benefit everyone - albeit especially the most disadvantaged - so the challenge, ironically, is how the less disadvantaged - the advantaged - benefit from remediating on behalf of disadvantaged pupils. It feels counterintuitive, but Rawls requires us to think about how bright pupils benefit from having less academically gifted pupils receive additional resources and compensations; for example, extra time in examinations. The issue has not been fully addressed to date because the problem is not recognised in utilitarianism, but it does have a philosophical 'solution' in a Rawlsian paradigm. Benefits accrue to advantaged pupils (and to advantaged sections of society) from the social coherence generated and secured by the fact that disadvantaged pupils get extra help. Cynics might suggest that they only receive enough support to 
maintain them in their domesticity, as it were, but a more harmonious, less turbulent society is to everyone's advantage educationally, culturally and economically. The same logic might apply to mixed-ability teaching: what bright pupils might lose in not being 'streamed' they gain from the harmonious atmosphere of the learning environment, which is why it is important to take account of peer-to-peer effects in measuring effectiveness.

Some commentators (see Philosophy Factory, 2011) see the Difference Principle as arguing for egalitarianism and the notion that everyone should have the same economic opportunities. This is true, but it is an over-simplification. Rawls (1971) is arguing for a more democratic society where inequalities (such as paying a higher salary to teachers in challenging schools) are permissible if they benefit the worst off (those in challenging schools). He believed that his theory of justice was compatible with a market economy and argued that unequal incomes were necessary 'in order to give the more talented the incentive to produce efficiently, to the benefit of all, including the worst off' (Callinicos, 2003), but this is not the same as the notion of meritocracy promoted by neoliberals and 'thirdway' social democrats like former UK prime minister Tony Blair, where individuals are entitled to extra resources simply because of their special talents.

Rawlsianism is not egalitarianism either. Egalitarianism prioritises simple equality. It is committed on a practical level to the removal of economic inequalities and insofar as education is concerned, to a system of schooling that achieves that end. Rawls's (1971) approach is more nuanced than this. His views on global distributive justice, for example, which surprised his egalitarian 
colleagues, recognised that aid should be given to states that were unable to protect human rights, but he held that the purpose for this aid was not to achieve equality, but rather to ensure that these societies could maintain liberal political institutions. And in fact he further argued that the prospect of indefinite aid creates a moral hazard whereby those who spend irresponsibly are underwritten and bailed out by those who spend prudently.

\section{The Galston critique of Rawlsian theory}

William Galston (1991) viewed Rawls's (1971) work as a systematic attempt to treat effort as morally arbitrary and irrelevant, although effort, according to Galston, is the one feature of working-class life that provides self-respect for the socially disadvantaged (Galston, 1991. pp.161-3). For Galston, Rawls severs the link between the 'willingness to produce' and the 'right to consume', replacing claims made on the basis of achievement with those based merely on existence (Mandle, 2009, p.31). Supporters of Rawls counter that this is a distortion of his theory and that the difference principle that Galston attacks is not there to evaluate individual shares, but to evaluate institutional and structural inequalities. Nevertheless, taking Galston's critique on board, Rawlsianism needs some modification before being applied to EER. For example, Rawls suggests that his two principles are actualised by society's institutions - the first by the political institutions; the second (both parts) by society's social and economic institutions - but EER might need to add a codicil for schools about the maturity of the education system under scrutiny and its cultural context. This has relevance particularly when making international comparisons. Would we 
expect schools in sub-Saharan Africa to actualise equity via its institutions in the same way as societies in Europe? Similarly, social mobility might be a political obsession in the UK, but it might not be a priority in developing countries where citizens might accept greater inequality (say) as long as it created jobs or alleviated famine (say), even if that inequality did not benefit the disadvantaged most, as Rawls requires. And in adapting Rawls, EER needs to discuss how all this relates to stability, which is an issue considered by the dynamic model of Creemers and Kyriakides (2008) ${ }^{12}$ just as it was in earlier EER research (Bosker \& Scheerens, 1994; Sammons, Thomas \& Mortimore, 1997; Scheerens \& Bosker, 1997; Teddlie \& Reynolds, 2000). Rawls suggests that his two principles make society more inherently stable, but is this necessarily the case in undemocratic societies like China?

\section{Part 3}

\section{Contrasting utilitarian and Rawlsian principles}

Rawlsianism argues that people would prefer to maximise the minimum amount of benefit that everyone gets under his principles, instead of maximising the average amount of primary goods that they receive under utilitarian principles (Freeman, 2003). This is an important point for EER because there is no measure or approach in EER that treats success against such a principle; that is to say, that the most successful school or schooling system is the one that maximises

\footnotetext{
12 When the dynamic model considers 'stage', it does not expect that all factors have the same functioning over the course of time. The 'context-specificity is shown by the differentiation in the functioning of the factors, which is taken into account when applying them not only at the classroom level but at the other levels too' (Kyriakides, L., personal communication, 3 May 2017).
} 
minimum pupil achievement, rather than maximises aggregated pupil achievement.

Rawls's (1971) principles secure equal rights for everyone, whereas utilitarianism restricts the basic rights of some for the sake of benefit to the many. Within the sphere of education, utilitarianism 'permits' us (in theory) to restrict a weak minority or deny them access to schooling - for example, by sending home weak or troublesome pupils during an inspection (although that is not something EER would condone) - if it produces greater utility, but it would be unacceptable (in theory) in Rawls's original position. In Rawlsianism, where everyone can see that everyone else has equal basic liberties, pupils see how the system works to everyone's benefit and are thereby incentivised by the prospect of cooperation based on mutual respect.

Another contrast is between the Rawlsian 'difference principle' and the 'restricted utility principle' of utilitarianism, which allows a society to maximise wealth with the only constraint being that the worst-off have a minimum income threshold. In education, for example, the state guarantees minimum provision for children up to an official school-leaving age and guarantees extra provision for pupils with special educational needs and other disadvantages (for example, free school meals for low socio-economic status pupils) while it simultaneously encourages advantaged pupils to maximise their attainment at all costs. This is the restricted utility principle in action, but those being schooled on the threshold of support will soon realise that they are being sacrificed to benefit the advantaged and as a consequence will withdraw from active participation and 
become disruptive. In any case, it is not clear that the principle of restricted utility delivers greater aggregate utility any more than Rawls's difference principle. Under Rawlsianism, people can still pursue their advancement. His principles are congruent with self-interest (without disadvantaging others), but it is a congruence 'of the right and the good' (Mandle, 2009) that requires a sufficient number of people to affirm the same principles of equity in the overlapping consensus. ${ }^{13}$

It is worth noting at this point that although the difference principle depends on the moral claim that it is unfair for people to benefit differentially because of differences between them that are not their fault, Rawls does not think that all arbitrary inequalities are unjust.

The natural distribution of natural talent is neither just nor unjust; nor is it unjust that some are born with a certain position. (Rawls cited in Mandle, 2009, p.24).

This has implications for the adaptation of Rawls to EER and to education generally: how to remediate for those who are born with less academic talent; how to deal with those who can pay for private education; and how to structure learning in schools given natural imbalances in ability. While Rawls (1971) advocates that social institutions like schools should transform natural contingencies into a fair share of outcomes like pupil attainment, he does not

\footnotetext{
13 This partly explains why education policy in fracturing societies is so chaotic; the system in inherently unstable because there is insufficient overlapping consensus.
} 
share the same understanding of distributive justice as those who simply believe that fairness requires us to correct all inequalities that are arbitrary. Rawls's principles themselves do not require society to even-out handicaps 'as if it were a horse race' (Mandle, 2009, p.25), especially those inequalities that come from natural endowment. Rawls does not hold that all inequalities are unjust; only that the original position from which the principles of equity emerge stops them from influencing the choice of principles. Rawls demands that those who have the same ability and talent, and the same willingness to use those talents, should have the same prospect of success. In EER, the narrow definition of 'success' that has come to us from utilitarianism means that within the aggregation of outcomes we rarely get to check who exactly is achieving what in schools, although this is partly addressed by differential effectiveness, and we rarely get to check whether or not existing educative processes, even if they appear egalitarian, benefit the most disadvantaged as much as they benefit the well-off. At a minimum, we should ensure that they do not accentuate disadvantage and a Rawlsian approach would help embed this into our methods.

\section{Conclusion: a new Educational Effectiveness Manifesto}

Although EER is at the cutting edge of empirical research, it faces challenges, one of which is its lack of a coherent underpinning philosophy. At its core, EER is concerned with equity and the contribution that schools can make to social justice, but so much attention has been given over the decades to methodology that by default the field has succumbed to the dominant utilitarian philosophy of policy-makers. There is little in the early school effectiveness literature to suggest that EER felt the need for a formal philosophy as such, so today there is 
little or no shared understanding within the field of what is meant philosophically, as opposed to methodologically - by 'fairness', 'justice' and 'equity'. Nor has there been any significant discourse on how the field has been corralled by the defining characteristics of utilitarianism; namely, the aggregation of utility and the primacy of a calculus that in the wrong paradigm can be spurious. This can mean, respectively, discounting pupils whose benefit is below average or accepting that one pupil's deprivation can be ignored because of another's achievement; and measuring intangibles in an inappropriate fashion or ignoring factors that are difficult to measure.

EER has been driven unwittingly into this utilitarian paradigm by policy-makers who see the convenience of ignoring peer-to-peer effects like well-being, altruism, bullying and friendship, and the relational nature of the human condition. In utilitarianism, there is no formal recognition given to the impact of these factors on outcomes, or to the impact of measurement on these factors, and yet, as Macmurray (1957, p.15) noted:

\section{All meaningful knowledge is for the sake of action, and all meaningful action is for the sake of friendship.}

Utilitarianism is a credible philosophy with a distinguished provenance, but its shortcomings make it unsuitable for EER because of the moral nature of education. It fails to uphold the intrinsic value of the individual above and beyond the collective, and as such it undermines democracy and the educative imperative. Practically also, utilitarianism is unsuited to EER's new dynamic 
models, which see effectiveness as something that is inherently changeable over time, yet no alternative paradigm has been advanced within EER to replace it. This paper suggests that EER should use Rawls's (1971) theory of justice as its new underpinning philosophy. His 'veil of ignorance' approach can help the field theorise about issues like the expansion of Grammar schools (Asthana \& Campbell, 2017), the fair allocation of increasingly scarce resources, streaming by ability and the welfare of high-achieving pupils in the state sector. These are issues that utilitarianism has failed properly to address because they are philosophical rather than evidential issues, and although EER has first class methodological equipment, it does not yet have the philosophical equipment to tackle them. A new 'effectiveness manifesto', based on Rawls's theory, would allow researchers to continue their progress towards warranting a fair system of schooling for everyone. It would redefine and realign the field without losing any of the methodological advances of recent years and would underpin the new dynamic approach of Creemers and Kyriakides (2008) by stating that:

- Educational effectiveness is multi-level in nature and dynamic in how it changes over time.

- An effective school is defined as one that increases educative benefit for all pupils, but increases the benefit for disadvantaged pupils more. Inequality is permitted and accepted only if it benefits the most disadvantaged, but everyone should benefit from remediation.

- Effective schools cannot correct for the fact that not everyone gets the same share of society's goods or nature's bounty, but schools can make a significant contribution towards redressing undeserved imbalances. 
- An effective school does not trade one pupil's failure for another's achievement.

- The metrics to measure effectiveness may include aggregate measures of utility at the level of the institution, but they should look primarily at specific educative benefit at the level of the pupil and the classroom. The objective is to gauge 'who' is achieving ' what' below the level of the school.

- The metrics to gauge systemic effectiveness will naturally look at aggregated benefit, but they should also take account of grouping at the meso-level between the institution and the system, such as with chains of schools and academy trusts.

- Controversial national policies can be considered using a veil of ignorance, with new experimental methodologies as required, to enable stakeholders to give preferences free from bias and self-interest.

- All methodologies, including those that enable benevolent and malevolent peer effects to be included, must pass a 'no-harm test' to ensure that they do not adversely affect the overlapping consensus.

By acknowledging the reality of inequality, a Rawlsian paradigm enables EER to take account formally of the benefit to every pupil, including academically bright pupils, of a harmonious learning and social environment in schools, and justifies philosophically taking account of peer effects. Rawlsianism also ensures that those who are lucky enough to be born with greater talents - or more accurately, with talents that are in greater demand at the time of asking - are not profiting at the expense of those less fortunate, while still being congruent with self-interest. As Rawls (1971, p.102) himself says of his own theory, stakeholders 'agree to 
share one another's fate'. This acknowledges the reality of schooling as a means of social advancement, but only provided there is sufficient overlapping agreement between different sections of society to affirm the same principles of equity.

It is clear that the utilitarian paradigm behind EER is threadbare, although Rawlsian theory needs some modification before being imported to replace it, particularly in terms of taking account of cultural context and systemic maturity. However, even as it stands now unmodified, it corrects the confusion between the benefit of a cohort and the presumed benefit of individuals within the cohort, which has forced EER into morally unintelligible positions like aggregating / averaging benefits that themselves are inherently individualistic. Utilitarianism might be convenient methodologically and it has led to useful insights, but ultimately it creates a wrong-headed paradigm and ignores the evolutionary basis of the empathy that people feel for each other. Those who have worked in schools know that pupils often sacrifice self-interest for comradeship, helping across the cognitive, conative and affective domains with academic work, socialisation and acceptance. This is ignored in utilitarianism, but there is no lack of willingness on the part of researchers within EER to attend to these influences and to assume a more suitable philosophical underpinning.

\section{References}

Alican, N. (1994). Mill's Principle of Utility: a defense of John Stuart Mill's notorious proof. Atlanta, GA. \& Amsterdam: Rodopi. 
Asthana, A. \& Campbell, D. (2017, March 6). Theresa May paves way for new generation of grammar schools. The Guardian. Retrieved from https://www.theguardian.com /uk-news/2017/mar/06/theresa-may-pavesway-for-new-generation-of-grammar-schools [Accessed 30 March 2017]

Bentham, J. (1780). An Introduction to the Principles of Morals and Legislation. (2007 edition, which is an unabridged republication of the Clarendon Press 1907 ed.). Mineola, NY: Dover Publications.

Bosker, R. \& Scheerens, J. (1994). Alternative models of school effectiveness put to the test. International Journal of Educational Research, 21, 159-180.

Brookover, W., Beady, C., Flood, P. \& Schweitzer, J. (1979). School systems and student achievement. New York: Praeger.

Callinicos, A. (2003 January). And Justice for All? Socialist Review, 270.

Charalambous, E., Kyriakides, L. \& Creemers, B. (2016). Promoting quality and equity in socially disadvantaged schools: a group-randomisation study. Studies in Educational Evaluation. Advance online publication.

DOI: $10.1016 / j . s t u e d u c .2016 .06 .001$

Retrieved from: http://dx.doi.org/10.1016/j.stueduc.2016.06.001 [Accessed 10 December 2017] 
Creemers, B. (2002). From school effectiveness and school improvement to effective school improvement: Background, theoretical analysis and outline of the empirical study. Educational Research and Evaluation, 8(4), 343-362.

Creemers, B. \& Kyriakides, L. (2006). Critical analysis of the current approaches to modelling educational effectiveness: the importance of establishing a dynamic model, School Effectiveness and School Improvement, 17(3), 347-366.

Creemers, B. \& Kyriakides, L. (2008). The Dynamics of Educational effectiveness: a contribution to policy, practice and theory in contemporary schools. Abingdon: Routledge.

Creemers, B. \& Kyriakides, L. (2015). Developing, testing and using theoretical models of educational effectiveness for promoting quality in education, School Effectiveness and School Improvement, 26(1), 102-119.

Dobert, H. \& Sroka, W. (Eds). (2004). Features of successful school systems: a comparison of schooling in six countries: Studien zur International und Interkulturell Vergleichenden Erziehungswissenschaft [Studies on International and Intercultural Comparative Education]. Münster: Waxmann Verlag.

Edmonds, R. (1979). Effective schools for the urban poor, Educational Leadership, 37(1), 15-24. 
Freeman, S. (Ed.) (2003). The Cambridge Companion to Rawls. Cambridge:

Cambridge University Press.

Galston, W. (1991). Liberal Purposes: goods, virtues and diversity in the liberal state. Cambridge: Cambridge University Press.

Gorard, S. (2014a, March 26). We still don't know what works in education. The Conversation. Retrieved from https://theconversation.com/we-still-dont-knowwhat-works-in-education-24382

[Accessed 2 April 2017]

Gorard, S. (2014b). The widespread abuse of statistics by researchers: what is the problem and what is the ethical way forward? Psychology of Education Review, 38(1), 3-10.

Hare, R.M. (1973) The Presidential Address: principles. Proceedings of the Aristotelian Society, New Series. 73, 1-18.

Hare, R.M. (1981). Moral Thinking: Its Levels, Method and Point. New York: Oxford University Press.

Harsanyi, J. (1975). Can the Maximin Principle Serve as a Basis for Morality? A Critique of John Rawls's Theory A Theory of Justice by John Rawls. The American Political Science Review, 69(2), 594-606. 
Harsanyi, J. (1977) Morality and the Theory of Rational Behavior. Social Research, 44(4), 623-656.

Hinton, T. (Ed.). (2015) The Original Position. Cambridge: Cambridge University Press.

Hutcheson, F. (1726). An Inquiry into the Original of Our Ideas of Beauty and Virtue. (Liberty Fund 2004 ed.). Indianapolis: Liberty Fund. Retrieved from http://oll.libertyfund.org/titles/hutcheson-an-inquiry-into-the-original-of-ourideas-of-beauty-and-virtue-1726-2004 [Accessed 30 March 2017]

Kyriakides, L., Creemers, B., Papastylianou, D. \& Papadatou-Pastou, M. (2014). Improving the School Learning Environment to Reduce Bullying: An Experimental Study. Scandinavian Journal of Educational Research, 58(4), 453478.

Macmurray, J. (1957). The Self as Agent. London: Faber and Faber.

Mandle, J. (2009) Rawls's A Theory of Justice: An Introduction. Cambridge: Cambridge University Press.

Mas-Colell, A., Whinston, M. \& Green, J. (1995) Microeconomic Theory. Oxford: Oxford University Press. 
McIntosh, E. (Ed.). (2004) John Macmurray: Selected Philosophical Writings.

Exeter \& Charlottesville, VA: Imprint Academic.

Mill, J.S. (1863) Utilitarianism. Retrieved from

https://www.utilitarianism.com/mill2.htm

Opdenakker, M.-C. \& Van Damme, J. (2000) Effects of schools, teaching staff and classes on achievement and well-being in secondary education: similarities and differences between school outcomes. School Effectiveness and School Improvement, 11(2), 165-196.

Philosophy Factory (2011). Rawls... an egalitarian or socialist? Retrieved from https://philosophyfactory.wordpress.com/2011/02/24/rawls-an-egalitarianor-socialist/

Popper, K. (1945). The Open Society and its Enemies. London: Routledge. [This book was reissued in one volume as Popper, K., Ryan, A. \& Gombrich, E. (2013). The Open Society and Its Enemies. Princeton, NJ: Princeton University Press.]

Rawls, J. (1971). A Theory of Justice (1999 edition). Cambridge, MASS: Harvard University Press.

Rutter, M., Maughan, B., Mortimore, P. \& Ouston, J. (1979). Fifteen thousand hours: Secondary schools and their effects on children (1995 Paul Chapman ed.). London: Open Books. 
Sammons, P. (2007). School effectiveness and equity: making connections.

Reading: CfBT.

Sammons, P., Thomas, S. \& Mortimore, P. (1997). Forging links: effective schools and effective departments. London: Paul Chapman.

Scheerens, J. (2014). School, teaching, and system effectiveness: some comments on three state-of-the-art reviews. School Effectiveness and School Improvement, $25(2), 282-290$.

Scheerens, J. \& Bosker, R. (1997). The foundations of educational effectiveness. Oxford: Pergamon Press.

Sidgwick, H. (1874). Methods of Ethics (7th/1981 ed.). New York: Hackett Publishing.

Teddlie, C. \& Reynolds, D. (2000). The international handbook of school effectiveness research. Lewes: Falmer Press. 